Instructions for authors, subscriptions and further details:

\title{
http://mcs.hipatiapress.com
}

\section{"To Be a Man is not Easy": Everyday Economic Marginality and Configurations of Masculinity among Rural Ghanaian Youth}

\section{Isaac Dery ${ }^{1}$}

1) University of South Africa and South African Medical Research Council, South Africa

Date of publication: June $21^{\text {st }}, 2019$

Edition period: October 2019 - February 2020

To cite this article: Dery, I. (2019). "To be a man is not easy": Everyday economic marginality and configurations of masculinity among rural Ghanaian youth. Masculinities and Social Change, 8(2),171-194. doi: 10.17583/MCS.2019.4157

To link this article: http://doi.org/10.17583/MCS.2019.4157

\section{PLEASE SCROLL DOWN FOR ARTICLE}

The terms and conditions of use are related to the Open Journal System and to Creative Commons Attribution License (CC-BY). 
MCS-Masculinities and Social Change Vol. 8 No. 2 June 2019 pp. 171-194

\section{"To Be a Man is not Easy":}

\section{Everyday Economic Marginality and Configurations of Masculinity} among Rural Ghanaian Youth

Isaac Dery

University of South African and South African Medical Research Council, South Africa

\section{Abstract}

How might an African based knowledge critically cast doubt upon globally hegemonic notions and traditions in understanding and theorizing men and masculinities? This essay examines this question through a critical reading of what it may mean to be 'an emerging adult man'. The essay privileged a critical understanding of how poverty, poor crop yields, and climate volatility shape constructions of 'emergent adulthood'. Drawing on interviews with men from northwestern Ghana, findings suggest that emerging adult men are committed to their cultural obligations as heteronormative breadwinners, yet 'emergent adulthood' is complicated by status insecurity, vulnerabilities, and powerlessness. To negotiate emergent adulthood, informants combine migrating to Techiman and joining 'boys boys' to achieve social respect and recognition. To understand the meanings of emergent adulthood, I argue for analytical sophistication on multiple issues and daily struggles that encapsulate rural life.

Keywords: Masculinity, northwestern Ghana, migration, Social respectability, gender, poverty, Dagaaba. 


\section{"Ser un Hombre no es Fácil" Marginalidad Cotidiana y}

\section{Configuración de la Masculinidad en los Jóvenes Rurales de Ghana}

Isaac Dery

University of South African and South African Medical Research Council, South Africa

\section{Resumen}

¿Cómo podría un conocimiento, forjado en África, arrojar críticamente dudas sobre nociones y tradiciones hegemónicas a nivel mundial para comprender y teorizar sobre los hombres y las masculinidades? Este artículo examina esta pregunta a través de una lectura crítica de lo que puede significar ser "un hombre adulto" en la actualidad. El ensayo priorizó una comprensión crítica de cómo la pobreza, los bajos rendimientos de los cultivos y la volatilidad del clima dan forma a las construcciones de la "adultez emergente". Según las entrevistas realizadas con hombres del noroeste de Ghana, los resultados sugieren que los "hombres adultos emergentes" están comprometidos con sus obligaciones culturales como "breadwinners" heteronormativos, pero la "adultez emergente" se complica por la inseguridad del Estado, las vulnerabilidades y la falta de poder. Para negociar la "adultez emergente", se combina la migración a Techiman y la implicación a 'boys boys' para lograr reconocimiento social. Para entender el significado de la "adultez emergente", se plantea el análisis de múltiples temas y las luchas diarias que encierran la vida rural.

Palabras clave: Masculinidad, noroeste de Ghana, migración, Responsabilidad Social, género, pobreza, Dagaaba. 



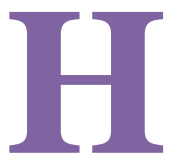

ow might an African (situated) knowledge critically cast doubt upon globally hegemonic notions and traditions in understanding and theorizing men and masculinities? In the past three decades, the question of how to progressively approach and study African men and boys within their multiple locatedness has received considerable scholarly attention and continues to engender deep debates among academic researchers and social activists across the African continent (e.g., Lindsay \& Miescher, 2003; Miescher, 2005; Uchendu, 2007; Adomako, Ampofo \& Boateng, 2011; Ratele, 2017; Mfecane, 2018). Contributing to global conversations on men and masculinities (Connell, 1995; Hearn, 2019), critical African theorists on African boys, men, and masculinities have moved for a more complex understanding of how African men and boys experience, circumnavigate, and enact gender at multiple levels based on their material, economic, and structural circumstances (Ratele, 2017; Mfecane, 2018). They encourage research on African men and masculinities to take seriously the multiple masculinities that exist between individual males and groups of males and how the individual male contest for patriarchal hegemonies within their multiple locatedness (Ratele, 2014). Importantly, African-centered research on men and masculinities must also pay attention to how colonialism, imperialism, and neo-liberal capitalism has contributed in shaping constructions and negotiations of masculinities and femininities in many important ways (Miescher, 2005; Uchendu, 2007).

Considering that the African continent is the youngest continent in the world, yet has the fastest growing and youthful population with a significant percentage of its population under the age of thirty (30), some scholars have pushed for a more robust understanding of the growing ambiguity, precariousness, and tenacity of masculine hegemony among young men in the continent (e.g., Silberschmidt, 2001; Lindsay, 2007; Uchendu, 2007; Groes-Green, 2009). Most of the literature demonstrates in different ways men's desire and psychological investment in economic power structures, masculine honor, and social status rooted in the effective male breadwinner figure. Despite men's aspiration for their breadwinning mandate, the prevailing socioeconomic realities fuel a considerable amount of masculine ambiguities, tensions, and frustrations in men's attempting to measure up to dominant views on masculinity. While young men with the 


\section{Dery - To Be a Man is not Easy}

requisite financial 'muscle' may likely enact masculinities congruent with traditionally hegemonic masculine roles (i.e., economic breadwinner), those who lack the requisite financial credentials to be successful breadwinners are likely to overcompensate their economic inability and status fragility through hyper-masculinities and extreme heterosexual posturing as noted by the existing literature.

The post-flag, West African state of Ghana represents a country where the demographic dividends of a relatively youthful population have not translated much into national development. In fact, the existence of a largely youthful population with diverse needs, expectations, skills, and interests is in and of itself is a difficult situation for both past and present governments to manage adequately. Much like elsewhere in Africa, as noted by Honwana's study (2013), there have recently been noticeable protests (peaceful), led by youth-based groups in Ghana (e.g., Unemployed Graduates Association of Ghana, Coalition of Unemployed Nurses) to denounce the rising levels of youth unemployment and the high cost of living. This has resulted in what is popularly perceived as 'youth in crisis.' In Ghana, most youths graduate from universities and colleges without any form of job for a long period and continue to be dependent on parents and relatives $^{1}$. Most Ghanaian youths are growing increasingly impatient as they feel deeply disappointed, disenfranchized, and sidelined by past and present governments that promised them that their bread would be buttered on both sides as part of political campaign messages. Young men and women play critically diverse roles in electioneering campaigns by forming an important political clientele base for political parties (Mueller, 2018), yet they are allegedly being ignored and abandoned by politicians after elections have been won, leading to what I describe as 'distorted citizenship.' The consequence of this 'distorted citizenship' is that young people, especially young men, are unfairly trapped in a zone of social limbo with very limited prospects for the present and future (Honwana, 2013). For young Ghanaian men to lay claim to the social privileges of adulthood, they need to get married, earn an income, build houses, buy fashionable clothing, and start their own families. This is extremely worrying and largely unattainable in northwestern Ghana (the focus of this essay) where poverty is highest, the rains are poor, the land is becoming depleted and farm produce is woefully inadequate for family consumption. Yet, not even 
within this troubled context are young men spared to function sufficiently regarding gender expectations and norms. The questions that may be of interest to gender critical researchers are: What does it then mean to be an emerging adult in a context where there seems to be little hope for developing better masculine profile? What practices, techniques, and actions do emerging adult men likely to deploy as vital strategies in order to gain social acceptance as meaningful social subjects?

Moving toward a critical discursive psychological understanding of how social identities interact with and mediated by a constellation of social categories, Kopano Ratele has advocated for 'marginality within hegemony' as a prism for critical understanding of the meanings of manhood in Africa. Ratele (2014) argues that any intervention that seeks to progressively approach and study African boys and men ought to be alert to the complex interplay between dominant notions of masculinity and political, economic, and social realities that circumscribe the daily life of men and boys in a deeply classed and capitalist-driven society. With this in mind, I believe that situating this essay within this theoretical understanding is necessary as it allows for a more thorough and careful consideration of how multiple currents significantly shape masculinities, including age, location, poverty, abled-bodiness, and capitalist hegemony. While emerging adult men may aspire for the position of independent breadwinners, they may be marginalized by their social, cultural and political circumstances which may compel a complex renegotiation of masculinities. Influenced by Ratele's theory of 'marginality within hegemony', the main goal of this essay is to bring into conversation new perspectives on what emerging adult men have hoped for, what ensues in their lives, and how they make sense of their masculinities in the process: what I call the 'early emergence' of adulthood. I argue for a theoretically rich interrogation and analytical sophistication of the vulnerabilities and subjectivities which confront emerging adult men, factors which have been obscured in the existing literature. Inasmuch as a broad-based understanding of diverse masculinities is concerned, acknowledging and understanding the complex and uncertain nature of being an emerging adult man in a particular cultural and social context is very important. Using 'emerging adulthood' as a productive prism through which a complex understanding of masculinities could be gained, this essay contributes to the growing body of literature on 
men and masculinities by articulating young men's voices and lived experiences, as well as presenting emerging adults as a more complex demographic group.

\section{Context of Research and Methodological Approach}

Research on men and masculinities is growing in Ghana. Such research draws broadly on historical sources, the print media, as well as contemporary sources and approaches (e.g., Miescher, 2005; Adinkrah, 2012; Adomako, Ampofo \& Boateng, 2011). However, the majority of the existing scholarship has concentrated on constructions of masculinities and femininities mostly in matrilineal and urban-based societies in southern Ghana. As a matter of contextual clarity, northern and southern Ghana differ in terms of cultural dynamics, social organization, and ecology. The three regions of northern Ghana, namely, the Upper West (UW) also known as northwest, Upper East (UE), and Northern remain (historically and currently) the poorest and most underdeveloped regions (see Lentz, 2006; Abdul-Korah, 2008). Although patriarchy is a common feature of the larger Ghanaian society, much like in the world, gendered roles, expectations, and boundaries are enforced in the UWR, especially among the Dagaaba (ethnic group of focus to this essay). In patrilineal families such as the Dagaaba, many intersectory factors, including age, social class, religion, gender, sexuality, marital status, ethnicity, and many others shape the production of multiple genders and subjectivities. For example, among the Dagaaba, these intersectory façades play a particularly significant role in producing social hierarchies between adult men and young men, between men and women, and among young men themselves. A greater proportion of the Dagaaba sustain their livelihood on rain-fed subsistence farming. As such, young men who are perceived by society not to have fully attained the status of adults work on their fathers' farms. With this as brief background contextual information, this essay contributes to critical debates on how emerging adults evaluate their masculinities in tandem with dominant notions of what it means 'to be a man', as well as how they position themselves within the larger gender and age hierarchies.

Methodologically, my research approach was qualitative in nature. Grounded in the everyday realities of participants, and in particular, how 
their everyday realities are shaped by the larger social, cultural and economic circumstances, participants shared with me what they thought were relevant to them as co-producers of knowledge. My acquaintance with these young men, coupled with my shared male gender, generational capital, and ability to speak the local language were hugely helpful as they facilitated access to the social world of these men without any perceived hindrance. I successfully conducted thirty (30) in-depth interviews with young men aged 25 and 30 across six purposefully selected Dagaare speaking communities in the region in 2016. I also interviewed an older parent (Gandaa, the village catechist) who was disturbed by his son's failure to live up to dominant masculine expectations of his generation. In analyzing the transcripts, I focused on consensus among participants across interviews on what it means to be 'an emerging adult man', as well as points of departure, ambiguities, and disagreements in various interviews. A thematic analytical framework was used to foreground the responses of participants.

In the next sections, I present and discuss two main themes as representative of the larger body of data. I situate my findings within the growing body of scholarly debates on men and masculinities in Ghana, Africa, and the globe at large.

\section{Migration as a Rite of Passage}

In the face of poor crop yields and erratic rainfall patterns, migrating to southern Ghana, especially Techiman (See appendix) became a common vehicle that almost all emerging adult men I have interviewed adopted and resorted to, to eke out an alternative livelihood, especially in the dry season. It is important to mention that rural-urban migration among the Dagaaba of northwestern Ghana is not a new phenomenon (Lentz, 2006; Abdul-Korah, 2007; 2008). But perhaps, what makes migration to southern Ghana more important for analysis today is that emerging adult men use migration as an important rite of passage of transition into meaningful social adulthood. The motivations and choices of emerging adult men to migrate today go beyond migration merely as an adventure to gain exposure to urban lifestyles and a survival mechanism as previous research claimed (AbdulKorah, 2007, p.92). 
Sitting in his newly roofed house listening to the radio with his son, Doozu, a 25 -year father tells me a lot on why he thinks that he has been relatively successful compared to his peers. As would be seen shortly, it was not for nothing that Doozu introduced me to his wife who was elegantly dressed. The impression on her face confirmed what her husband would want people like me to know about his supposed accomplishment. Doozu's son was also well-dressed in a fine-looking shirt, embossed with the image of popular American rapper, 50 Cent, although the shirt looked oversized. Speaking in a rather boastful manner and consistently drawing my attention to his 'Black and White' TV set, even though their community has no electricity at the time of the interview, Doozu narrated:

When I was growing up, my father used to farm a small piece of land and harvest enough to feed us and even sell surplus to buy us clothing for Christmas. Today, it is not the same. You even farm on a much larger piece of land and the yields are so hard to believe. How do you sell some to fulfil other obligations? Your children and wife all look up to you as the yirdandso [man of the house]. When you're unable to meet your obligations as a man, people will laugh at you as dos kon taa tege. That is why we travel to Techiman. At least that gives us some extra money. As you can see for yourself, I have just returned from Techiman and my family is happy. My wife is wearing new clothes and her colleagues are always jealous because their husbands cannot provide.

Corroborating how rural economy is failing men in their bid to build better masculine profiles and the pain associated with this sense of failure, Baakye, a 26-year father explained further:

Nowadays, the rains are failing us. That makes it hard to be a 'man' here... I mean to be a 'man' is not easy. But that is not any excuse to relinquish your responsibility as a yirdandos. That is the fact. You know my friend Bayor whose house is located down there in the community, his wife does not respect him enough because he has become a 'woman'.

Interviewer: How do you mean by Bayor has become a 'woman'? 
Baakye: Bayor only has a penis, but he is indirectly a 'woman'. We all know that the situation is difficult here, but you don't need to give up. Men are like hunters. Bayor has failed to function as a 'man'. His wife wears the same clothes everyday. When others are travelling to Nkoranza [in southern Ghana], he will refuse. He is a lazy man. A man is respected when you're able to provide for your family. Women like to wear new clothes to show off. When your wife wears something new, it shows that you're taking care of her. Your ability to do this differentiates you as a responsible man from your colleagues.

Dakora, a 23-year father of one child was aspiring to travel in the next season starting in January 2017. Although Dakora was proud of being a father, he was worried that people may not accord him greater respect compared to his peers who were relatively wealthy by community standards. Like his peers, Dakora reiterated how poor crop yields and unpredictable rainfall patterns are hitting so hard on emerging adult men in their attempts to become meaningful social subjects. Even though he, like his peers, lamented about how the local economy has changed in recent years, Dakora believed that to be 'a man' is to be able to pick the bits and pieces from the prevailing circumstances and move ahead with life. To him, this is a key marker of manhood. He shared his motivation to travel:

For me, a young man like me without money is like a 'bicycle without a tube'... No woman wants to associate herself with [a poor man] like those village champions [cause] you can't take care of her needs. The pride of every young man is to see his wife look happy. Real men are known by the kind of clothes their wives wear to funerals, market, and church. You know that feeling.... Therefore, I want to travel next season so that people will respect me as a real man.

Participants articulated how the feeling of public shame and gender performativity, emanating from neoliberal capitalist ideologies shape the everyday struggles of rural men in different ways. Participants articulated that men have a cultural obligation always to strive to provide for their families. The notion that desirable masculinity is rooted in a man's ability to provide for his family has been an enduring reality that participants have 
witnessed while growing up. Most participants alluded to this reality when they suggested that their fathers could use the farm produces to feed the family, as well as meet other material requirements necessary for traditional masculinity. Because participants are burdened by poor crop yields caused by climate volatility, which significantly threatens men's ability to fulfil core cultural obligations as breadwinners, traveling to southern Ghana serves two functions: it constitutes an important point of ritual transition into meaningful adulthood, and secondly, life after a migration expedition is potentially more socially profitable as it facilitates emerging adult men to legitimize and further validate their social statuses as 'real men'. Migration enables men to acquire money, which allows them to marry, and to purchase consumer goods, such as clothes, particularly for their girlfriends and wives.

Reading through the excerpts above, it is evident that dominant notions of masculinity contribute to the overall dominance of men as a collective social group over women. The dominance of men over women is aptly derived from widespread patriarchal stereotypes. Men enhance their masculine dominance and patriarchal hegemony over women through heteronormative marriage; an important cultural terrain which bequeaths men the moral authority always to expect women to respect them. Understandably, traditionally valued masculine ideals such as men as breadwinners serve to further legitimize men's interest in the benefits of association found in heteronormative marriages. Patriarchal stereotypes are deeply woven into the larger social fabric which always encourages 'real men' to aspire for positions of power through various ways including migration. Drawing on feminist theory of intersectionality, one might be interested in analyzing the relational nature of power between men and women in broad terms as well as among men themselves. From the excerpts above, it is noteworthy that men always aspire to wield power while simultaneously being oppressed by that same power. Men experience power in their position as heteronormative breadwinners, yet the oppressive nature of this patriarchal stereotype is far-reaching for men themselves. This becomes more glaring in a context where climate vulnerabilities are deeply undermining and threatening the very essence of patriarchal masculinities. The narratives of men in this essay call for a thorough analysis of power and how power resides in and circulates among social subjects. It is 
common to suspect that in gender inequitable societies such as northwestern Ghana; the impact of climate change may reinforce and exacerbate existing inequalities between men and women. Yet it is also true that in such a patriarchal context where rigid gender norms and expectations are strictly enforced and most people sustaining their livelihood on rainfed agriculture, more men compared to women are likely to be affected negatively by climate change volatility.

In rural communities in northwestern Ghana, social gatherings such as markets, churches, and funerals are important social spaces for both good and bad reasons. Social events among the Dagaaba are key domains for performing and negotiating the politics of personal pride, honour, and reputation. Social events also constitute important sites for the performance of social identities. For example, funerals bring people together to sympathize with the grieving family. This deepens social networks and capital. At the same time, funerals also function as political spaces for making various claims. For example, at funerals 'real men' and 'real women' are able to distinguish themselves from the 'ordinary other', personified by their clothing. It appears that the easiest way that an emerging adult man can clearly demonstrate his masculinity in the community revolves around the kind of clothes such men's wives wear illustrated by Dakora's comment 'Real men are known by the kind of clothes their wives wear to funerals, the market, and church.' Clothing has been socially constructed as a fundamental artefact in the way men negotiate, evaluate, and validate their masculinities in relation to other masculinities. Masculinities are thus expressed as profoundly theatrical: a man must demonstrate command of various masculine ideals (through the codes and choices of dressing of his wife) in order for others to validate his position as a 'responsible man' beyond biological indications. Despite their own acknowledgement that the economic situation is difficult, participants knew too well that they had much to gain from being hard working even if this may mean going the extra mile to fulfil the prevailing codes of manhood. It thus seems accurate to conclude that a person attaches various currency to versions of masculinities and femininities depending on what his wife wears daily. Mundane as this may seem, the desire to fulfil this notion of masculinity creates huge tensions and conflicts between emerging adult men, between those who can meet this requirement and those who are 


\section{Dery - To Be a Man is not Easy}

unable. The perception that it is a husband's responsibility to provide clothes for his wife highlights how the discourse of values of social honour, materiality, and public respectability are deeply and complexly intertwined in the Dagaaba marriage economy. A husband's ability to fulfil this cultural mandate is a demonstration of his commitment to maintaining a 'happy' and 'peaceful' marriage. My findings are consistent with those of Hannaford and Foley (2015). According to these authors, men in Senegal thought that it is their primary responsibility to provide clothing to their wives. Providing clothes to wives does not only contribute to 'fashion', but the practice is increasingly becoming codified as part and parcel of the performances of credible masculinities.

The 'aesthetic' relevance of women publicly advertising and communicating the masculine credentials of their husband through clothing is particularly important for critical analysis for strategic and political reasons. Throughout my interaction with participants in this study, there is high tendency that wives are always expected at least by their husbands to demonstrate the wealth and commitment of the latter. In fact, this practice may be a strong evidence to confirm that a husband is 'responsible', and by extension, his wife is happily enjoying her relationship. While it is extremely important to highlight how 'real men' always feel proud because their wives wear 'fashionable clothes' ('Real men are known by the kind of clothes their wives wear'), this practice potentially reinforces dominant patriarchal ideals on emphasized femininity. Traditionally, Dagara women who aspire to the position of a pogminga (interpreted variously as 'ideal woman', 'responsible woman', or 'good woman') dress decently and behave modestly in order to avoid any possible suspicion that could potentially ridicule the image of a husband figure. While the political functions of clothing have become a common thread that binds participants' narratives in complex ways, there is no equivalent attention given as to how 'real men' should dress.

In all my conversations with participants, there is an emerging logic of 'money' as a core symbol of social authority, status, voice, and respect among emerging adult men. This argument resonates with Lindsay's (2003) analysis of masculinities in postcolonial Nigeria. Lindsay's work emphasizes the importance of money and what it means to lack money as a 'man'. Without money, participants allege that an emerging adult man is 
less respected in comparison to his peers who have access to financial hegemony. The evidence thus suggests that to be the ideal emerging adult man is to be financially independent; otherwise a man becomes a 'bicycle without a tube'. This metaphorical expression draws attention to two interrelated insights. First, money is constructed as a defining factor in what it means to be 'an emerging adult'. Second, to lack money is to be socially, economically, and culturally impotent and possibly emasculated illustrated by the phrase 'doo kon taa tege'. Dos kon taa tege can literally be interpreted as 'a man without meaning', 'a man without focus', 'a useless man', 'a poor man', and 'an emasculated man.'

\section{Destabilized Identities: Constructing Failed Masculinities in a Precarious Situation}

While conducting interviews in the early hours of April 1, 2016, distressing news broke out that several Dagaaba young men were stranded and needed urgent support in Techiman. The situation was described by most of these young migrants I later interviewed as 'survival of the fittest'.

Ntole-ang, a 24-year old son of the village catechist Gandaa, was among the stranded group of young migrants and was frequently mentioned in the locally circulating news. Gandaa was deeply devastated when he first heard that his only son was not physically strong enough to compete favourably with his peers on the farm in far away Techiman. In my first encounter with Gandaa and in a dismissive voice, he queried himself: "What did I do wrong to deserve this shame if what I am hearing is true? As a father, I know I have trained him well. I don't deserve this embarrassment". A week later, I encountered Mwinela-naa, one of the five young men who travelled with Ntole-ang as a group. In northwestern Ghana, it is common practice that young migrants travel in groups. Mwinela-naa had brought Ntole-ang back home from Techiman and wanted to return immediately because he had not achieved enough to enable him to pay his wife's bride price and meet other family obligations.

In a conversation with Gandaa, after the return of Ntole-ang who had grown extremely thin and looking physically weak, an incredibly disappointing impression was revealed. According to Gandaa, Ntole-ang had brought virtually nothing with him apart from two things: first, he had 
brought what Gandaa described as 'irredeemable shame' to the family; and second, he had only managed to bring an almost empty 'Ghana Must Go' $\mathrm{bag}^{2}$; a bag which was not comparable to those of his peers. In a frustrated voice, Gandaa shared this:

I don't know where to start. You and I know very well that giving birth to male children is the pride of every father. I mean, they [sons] are the heirs of the family. If I had not given birth to a son, it would have probably been better. My son, [Ntole-ang] is next to nothing... While his peers travel and bring property and lessen the burden of their families, Ntole-ang is a huge disappointment. He did not even bring 'common bread'. Nothing! How should I [as a father] possibly be happy with this? I don't know what to say to my colleagues when they talk about their sons who are doing very well. $O$ kong tuong poge bine.

The most immediate fear that underpins Gandaa's and most participants' expression of frustration is a perceived masculine deficiency, shame, and powerlessness. The feeling of masculine deficiency and shame which was a common theme across the transcripts is perhaps most warranted in a rural context where poverty levels are high and crop yields are poor. The feeling of being an unsuccessful 'man' leaves most participants with the nagging feeling that they have performed (in their capacity as fathers and adult sons) below the ascribed standards set by the emergence of new vocabularies of respectable masculinities. These new vocabularies such as personal pride, values of honour, and reputation, rooted in neo-liberal capitalism and materiality, set in motion new conventions on manhood which both fathers and sons are encouraged to always aspire for. Importantly, masculine respectabilities are achieved in an ongoing manner and not end-goals in themselves. Herein lies the significance of the metaphor of the male child figure and what it may mean for a father to have a male child who fails to impress society. The male child figure has been foregrounded in this essay as an important social insurance for greater masculine respectability. This perhaps explains Gandaa's own psychological disillusionment when his only son failed to live up ruling norms on manhood. The interlocutor's personal disappointment should be taken seriously, especially in a patriarchal context in which proudly telling other colleagues, of success 
stories and achievements of male children has assumed a deeply political and hierarchical dimension as a source of masculine gratification. The failure of Gandaa's son has brought the reputation of his fatherhood into serious disrepute ('How should I, as a father, possibly be happy with this?'). The narratives of Gandaa draw attention to the existence of hierarchies of masculinities within the same social context.

The phrase "o kong tuong poge bine," can be roughly translated as "he cannot even do anything women can do with much ease," or "he is far below anything men are supposed to do," speaks to discourses on masculinity and femininity. This expression resonates with what participants described above as a 'bicycle without a tube.' The training that Gandaa used to strengthen and prepare Ntole-ang, as a form of future social insurance did not yield much dividend, but rather produced worrying feelings of social stigma and a dented image as a father. The failure of his only son has hugely ruined some anticipated masculine joy and pride; a common feeling of fathers who see themselves as traditionally masculine.

Ntole-ang himself was equally disappointed in his failure to live up to his parents' and socially ascribed expectations thus falling short of dominant masculine ideals such as acquiring material property and being heterosexually married. The impression on Ntole-ang's face as I engaged him in the interview suggested feelings of shame, worthlessness, and hopelessness. The interview session with Ntole-ang was full of disturbing sounds from his voice. In a faint voice and, looking down at the ground, thus avoiding eye contact with the interviewer, he narrated:

I know I have disappointed my parents. See... I am stuck in life without any form of meaning or prospects. No property. No wife. No child. No respect. Nothing! I am just an 'ordinary man'. All my peers are doing very well and married with children. At my age, society expects me to be a 'man'...um, you know, sort of get married and be a family provider. Nobody respects me because I'm just an ordinary man. Just look at me; what is the worth of life? I think this life is not worth it. Even if I kill myself now, it is far better than this sort of frustrating and empty life.

First of all, it is significant to highlight that it is not in Ntole-ang's best interests to invoke the question of masculine alienation. While invoking this 
question leaves his own masculinity in a very precarious and unfavourable position, he is simultaneously caught in what appeared to be an ideological dilemma. At the core of this ideological dilemma are patriarchal structures and stereotypical notions of patriarchal masculinities deeply rooted in heteronormativity and its attendant privileges. Ntole-ang appears to be in a deep ideological battle in which his own aspiration for specific models of masculinity have been compromised by forces beyond his control. The interlocutor draws attention to how his inability to fathom socioeconomic realities has left him remarkably bereft of the legitimizing imperatives of patriarchal ideologies. He is deeply troubled by the range of expectations that society places on him, yet he lacks what it takes to be a 'real man' in the eyes of society. He admits that his inability to command and possess culturally celebrated qualities has denied him privileges associated with traditionally-acclaimed masculinities such as fatherhood, heteronormative marriage, material property, and social respect. Comparing himself with his compatriots, the interviewee painfully articulates that his inability to command dominant masculine ideals has significantly affected his masculine worth in the larger social hierarchies. He describes his experiences as deeply 'frustrating' and 'meaningless'. To him, emerging adult men are only worth their salt when they possess property, are heterosexually married, are fathers, and are socially respected. In his own mind, he falls woefully short of his peers because he has not achieved these fundamental milestones. This has given him every reason to believe that he is a failure illustrated by the phrase "I am just an "ordinary man". Here, we see Ntole-ang constructing himself as the 'other' of his peers.

Ntole-ang's sense of disappointment, powerlessness, and ambivalence to life deserves special commentary, especially in preventing psychological, mental, and traumatic stress disorders. On one hand, his feelings of culpability, emptiness, and loss of masculine honor can be understood at a very practical level where global capitalism and the myths of a capable breadwinning male figure have become important parameters in measuring idealized masculinities (Silberschmidt, 2001; Groes-Green, 2009; Honwana, 2013; Masquelier, 2013; Izugbara, 2015). Ntole-ang's lack of these achievements underpins his own disappointment and subsequent suicidal thoughts (Adinkrah, 2012). Masculinity is likely to turn toxic when men suffer profoundly from mental and social pain owing to the pressures 
of unrealistic expectations from society in a highly humiliating and humbling context.

Ntole-ang's suicidal thoughts highlight the excesses of toxic patriarchal masculinities firmly rooted in men's inability to be vulnerable and independent in the crudest of circumstances (Adinkrah, 2012; Izugbara, 2015). By positioning themselves as 'grown-up', at least, in terms of body stature and age, all adult men are traditionally required to earn their reputation by being independent and demonstrating command of the traits of a successful heteronormative breadwinner; an argument consistent with the findings of Izugbara (2015), Honwana (2013) and Cassiman (2010). Against this backdrop, negotiating one's position in the masculine hierarchy is virtually impossible. Ntole-ang sees himself as a physically mature adult man, but psychologically, socially, and culturally, he is not adult enough by community standards. He has attained the position of an emerging adult male by age, but by virtue of his inability to fit into dominant frameworks determining respectable masculinities, he is accorded less respect. This finding supports my own theorization of emerging adulthood as a much more complex, yet fluid, ambivalent, and context-sensitive demographic category which is shaped by, political, social, economic, and emotional dilemmas, and paradoxes, and embodied cultural processes and experiences.

To other participants, Ntole-ang might not have done enough to salvage himself from a humiliating world. The narratives of other participants suggest that helplessly succumbing to the harsh situation as an emerging adult is not good enough. To be an emerging adult man is to strive hard to avoid shame and ridicule, irrespective of the situation as explained by Kuuire-ma, a 27-year old father:

You know; the situation is hard here...You come here, you smell poverty everywhere. The lands are not fertile again as they used to be. Sometimes, things are not really working. But you're a man and you need to face the situation. You're not a [woman] who will just sit down, fold your hands and complain. Men don't complain. You need to fight harder and figure things out. Things might improve later. 
Kuu-ire-ma's comment above is interesting for a number of reasons. At one level, he offers some form of consolation that a man should not necessarily be deemed failure if he fails to fathom his way in a system in which poverty is deep-seated. At a different level, the speaker's position is deeply problematic as he has linked masculinity with proactivity, strength, optimism, toughness, and always needing to 'man up'; qualities that are commonly associated with dominant masculinities (Uchendu, 2007; Ratele, 2014). As Kuu-ire-ma admits to the pervasiveness of poverty, he immediately suggests that a young man worth his salt when he takes his identity into his own hands. While the interlocutor argues that poverty is widespread, he simultaneously essentializes vulnerability as a feminizing trait. Kuu-ire-ma's argument speaks to the predicament of his compatriot, Ntole-ang, although these participants come from different communities. $\mathrm{He}$ advises that the position of the 'ideal man' (as opposed to the ideal woman) means that one works harder during extremely difficult times without complaining ("Men don't complain"). Previous research in Ghana and Kenya has highlighted the fact that a man's failure to confront his future and take his destiny into his own hands, is a serious violation of traditional codes of masculinity and that such a masculine indictment is a major topic of strong social derision (Abdul-Korah, 2007; Adinkrah, 2012; Izugbara, 2015).

Despite their economically marginalized position in relation to adult masculinities, emerging adult men in this study are constantly being challenged and motivated by their circumscribed position in society. They seek to invent and reinvent themselves as self-acclaimed social adults while simultaneously being invented and reinvented by the de-masculinizing and humbling socioeconomic contexts in which they live. To negotiate the complexities and contradictory experiences, young men engage in 'boys boys'. 'Boys boys' is a local terminology commonly associated with a male only group whose membership is comprised of 'emerging adults.' The concept of 'boys boys' emerged as a powerful homosocial interface which creates a productive space for emerging adult men (both married and unmarried) to socialize and network. Emerging adult men resort to 'boys boys' as an important alternative route to validate and strengthen their sense of masculinity in various ways. It is a hierarchically structured group with leaders. Members meet daily at a common meeting ground mostly under 
shacks or trees. Community members are aware of such meetings. Understandably, 'boys boys' creates an important sphere for negotiating relations of power and social identity among emerging adult men. The practice of 'Boys boys' has emerged as a crucial space for the mobilisation and configuration of a particular model of masculine persona rooted in the conspicuous drinking of hard liquor (akpeteshie, a locally brewed gin with high alcohol content) and consumption of marijuana. Participants argue that they engage in these activities to compensate themselves for certain masculine inadequacies such as the inability to perform as economic breadwinners. With patriarchal authority and economic power mostly vested in the hands of older adult males, especially fathers, emerging adult men gain some sense of independence through the political space of 'boys boys'. It must also be highlighted that the use of alcohol and smoking cigarettes/ marijuana have become vehicles not only for a power struggle between emerging adult men and older adults such as fathers, but also among emerging adults themselves. As explained by Ntole-ang: "When you don't possess authority at home, I mean life being hopeless, alcohol pays for that. When you drink, you forget about what people think you're not'.

Embedded within participants' narratives is the framing of 'boys boys' as an important political exit strategy; a viable option which presents a medium of disconnecting from the political and patriarchal world of the family (Masquelier, 2013). Because of their acquired position of social independence and leadership position embedded in 'boys boys' as an autonomous space for the imagination of novel models of masculinities, parents do not strictly regulate the activities of these young men. Consequently, the latter tend to abuse alcohol as an escape from an endangered and threatened social world in which the authority of their parents rules their sense of autonomy and self-identity. Frustrated by harsh socio-economic realities of contemporary northwestern Ghana, alcoholism and smoking are a radical departure from previous generations when these acts were considered the preserve of the adult rich, 'big men' (see Akyeampong, 1996).

\section{Conclusion}

In this essay, I have sought to unravel the meanings of being an 'emerging adult' man and how 'emergent adulthood' is intricately bound up in status 


\section{Dery - To Be a Man is not Easy}

insecurity, vulnerabilities, poverty, and a sense of powerlessness. My findings both confirm and deepen the existing body of knowledge on what it may mean to be 'a man' in sub-Saharan Africa, as well as extend the debates further in significantly new ways by re-centering the voices and experiences of a demographic group that has remained less written about in Ghanaian masculinity literature. My findings confirm that money is connected to social respectability, honor, status, authority, and social identity. The emerging adult men in this study are aware of the patriarchal power of their male identity, yet they are likely to experience status vulnerability, conflict, and insecurity in the absence of money. They articulate that their masculinities as emerging adults are likely to be deflated and in doubt when they lack economic power. Money enables emerging adult men get married and pay their wives' bride price, become fathers, buy their wives fashionable clothing, and eventually breadwinners. My findings suggest that living in a poverty-ridden and climate-volatile context, such as northwestern Ghana as an emerging adult man can be incredibly frustrating and disempowering as there are fewer viable opportunities to strengthen rural masculinities and/or construct alternative masculinities without resorting to external intervention. While emerging adult men are deeply invested and committed to their cultural obligations as heteronormative breadwinners, it appears most of them are suffering within a system which is failing them. The system is frustrating, yet society requires that men earn respect, achieve social power and positioning in the gender hierarchies by adequately fulfilling varying ideals of masculinity. With pressure mounting on emerging adult men to achieve respect, honor, and social recognition daily emerging adult men relentlessly work to challenge and confront the challenges that life throws at them by exploring, reinventing, and finding alternative possibilities such as migrating to Techiman, as viable ways of sustaining their marriages. Through 'boys boys', emerging adult men also reposition themselves as independent social subjects through their actions in ways that resuscitate masculine meaning in lieu of their lack of economic power. Acknowledging the range of conflicting forces, ambiguities, and vulnerabilities among emerging adult men is an important contribution to gender critical and African-situated scholarship that resists a simplistic representation of the meanings of emerging adulthood. To contribute to developing alternative imaginations 
of manhood, the ultimate goal of African-situated research should aim at creating impactful knowledge that liberates African men rather than reproducing western standards on gender identities. One way that my own research contributes to this decolonizing attempt is allowing emerging adult men to be at the center of their own lived experiences and realities as active agents. Researching the kinds of complexities, vulnerabilities, and uncertainties articulated by emerging adult men in this essay is a potentially empowering and therapeutic intervention, as emerging adult men take center stage in narrating their own aspirations and how they negotiate masculinities in complex ways. While acknowledging their supposed patriarchal privileges as males, the benefits and disadvantages of their male identity simultaneously confront emerging adults. In arguing for the role of agency and reflexivity, action and reflection to be prioritized in research on emergent adulthood, the process of allowing emerging adult men to share their stories, aspirations, pain, and mental processes on what it may mean to be 'a man', on one hand, and the practical realities and daily struggles of rural life, on the other hand, may be beneficial. It is safe to presume that this process would permit emerging adult men to recognize their own masculine vulnerabilities and precariousness, and in particular how destructive adherences to particular gender stereotypes could be to men themselves as well as to women. This approach is an innovative effort to engage men in Ghana broadly in interventions with a strong focus on developing and promoting liberatory masculinities.

Reading through the narratives of participants, it is difficult, if not impossible, to talk of a consistent and stable hegemonic masculinity as advocated by Connell (1995). As revealed in the narratives of participants in this study, the most esteemed attributes of manhood include heterosexual marriage, economic breadwinner, fatherhood, physical and emotional fortitude, independence, and material possession. These are embodied practices of manhood deeply infused with power. These modes of manhood do not exist independently of one another. Rather, they interact and struggle for dominance, normativity, and legitimacy at different times. It is arguably true that a man's financial prowess may enable him to function as a heteronormative breadwinner. Men in this category stand a higher chance of being respected by family relations and community broadly within the social hierarchies. While this could be interpreted as hegemonic in nature, it 
does not necessarily subordinate other forms of masculinity such as those embedded in homosocial network. For many gender critical researchers in Africa, such as Kopano Ratele, the idea of gender hegemony is a very slippery and unsustainable construct hence multiple hegemonies could prevail in a specific social context.

As a caveat to the findings contained in this essay, it is relevant for future research to interrogate how women are also working to fulfil their part of the patriarchal bargain in sustaining 'peaceful' heteronormative relationships.

\section{Acknowledgments}

I am extremely grateful to my participants who generously shared their experiences, thoughts, and hopes with me. I also want to express my sincerest gratitude to the following people who generously shared their time, thoughts, and constructive comments on my manuscript at various stages: Dr. John Ganle, Prof. Stephan Miescher, Prof. Abdul-Korah Gariba and Prof. Benjamin Lawrance. I am deeply appreciative of your mentorship.

\section{Funding Details}

Funding for this study was part of a doctoral fellowship supported by the Social Science Research Council's Next Generation Social Sciences in Africa Fellowship, and Association of African Universities (AAU) Small Grant for Thesis Completion. However, the funders did not contribute to the design, data collection, analysis and writing of this manuscript.

\section{Notes}

${ }^{1}$ Citinewsroom.com April 23, 2018. Bonded unemployed nurses, midwives protest over delayed posting. Available at

https://www.ghanaweb.com/GhanaHomePage/NewsArchive/Bonded-unemployed-nursesmidwives-protest-over-delayed-posting-645701. Accessed on December 10, 2018.

2 The 'Ghana Must Go' bag is a type of bag Ghanaians who were deported from Nigeria following the 1982 economic crisis, carried.

\section{References}

Abdul-Korah, B. G. (2007). 'Where is not home?': Dagaaba Migrants in the Brong Ahafo Region, 1980 to the Present. African Affairs, 106(422), 71-94. doi: 10.1093/afraf/adl023 
Abdul-Korah, B. G. (2008). 'Ka Bic Ba Yor': Labor Migration among the Dagaaba of the Upper West Region of Ghana, 1936-1957. Nordic Journal of African Studies, 17(1), 1-19. Retrieved from https://www.africabib.org/htp.php?RID=322354919

Adinkrah, M. (2012). Better dead than dishonored: Masculinity and male suicidal behavior in contemporary Ghana. Social science \& medicine, 74(4), 474-481. doi: 10.1016/j.socscimed.2010.10.011

Adomako Ampofo, A., and Boateng, J. (2011). Multiple Meanings of

Manhood among Boys in Ghana. In Sylvia Tamale (Eds.), African

Sexualities: A Reader (pp. 420-436). Cape Town: Pambazuka Press. Akyeampong, E. (1996). Drink, Power, and Cultural Change: A Social History of Alcohol in Ghana, c.1800 to Recent Times. Portsmouth, NH: Heinemann.

Cassiman, A. (2010). Home call: absence, presence, and migration in rural

Northern Ghana. African Identities, 8(1), 21-40.

doi:10.1080/14725840903438269

Connell, R. W. (1995). Masculinities. Cambridge, UK: Polity.

Groes-Green, C. (2009). Hegemonic and subordinated masculinities: Class, violence and sexual performance among young Mozambican men. Nordic Journal of African Studies, 18(4), 286-304. Retrieved from https://pdfs.semanticscholar.org/3047/23961b36f9af8038ad2defae07 6909bd48b8.pdf

Hannaford, D., \& Foley, E. E. (2015). Negotiating Love and Marriage in Senegal: A Good Man is Hard to find. African Studies Review, 58(2), 205-225. doi:10.1017/asr.2015.44

Hearn, J. (2019). So what has been, is, and might be going on in studying men and masculinities: Some continuities and discontinuities. Men and Masculinities. doi:10.1177/1097184X18805550

Honwana, A. (2013). Youth and Revolution in Tunisia. London: Zed Books. Izugbara, C. O. (2015). 'Life is Not Designed to be Easy for Men':

Masculinity and Poverty Among Urban Marginalized Kenyan Men.

Gender Issues, 32(2), 121-137. doi:10.1007/s12147-015-9135-4

Lentz, C. (2006). Ethnicity and the making of history in Northern Ghana. Edinburgh, Scotland: Edinburgh University Press.

Lindsay, L. A. (2003). Working with Gender: Wage Labor and Social Change in Southeastern Nigeria. Portsmouth, NH: Heinemann. 
Lindsay, L. A. (2007). Working with Gender: The Emergence of the 'Male Breadwinner' in Colonial Southwestern Nigeria. In Catherine M.

Cole, Takyiwaa Manuh, \& Stephan F. Miescher (Eds.), Africa After Gender? (pp. 241-252). Bloomington: Indiana University Press.

Lindsay, L. A., \& Miescher, S. F. (2003). Men and Masculinities in Modern Africa. Portsmouth, NH: Heinemann.

Masquelier, A. (2013). Teatime: Boredom and the temporalities of young men in Niger. Africa, 83(3), 470-491.

doi:10.1017/S0001972013000272

Mfecane, S. (2018). Towards African-centred theories of masculinity.

Social Dynamics, 44(2), 291-305.

doi:10.1080/02533952.2018.1481683

Miescher, S. F. (2005). Making men in Ghana. Indiana University Press. Mueller, L. (2018). Personal Politics without Clientelism? Interpreting Citizen-Politician Contact in Africa. African Studies Review, 61(2), 28-54. doi:10.1017/asr.2017.131

Ratele, K. (2014). Currents against gender transformation of South African men: Relocating marginality to the centre of research and theory of masculinities. NORMA: International Journal for Masculinity Studies, 9(1), 30-44. doi:10.1080/18902138.2014.892285

Ratele, K. (2017). African (situated) psychologies of boys, men and masculinities. Psychology in Society, 54, 10-28. doi:10.17159/2309$8708 / 2017 / \mathrm{n} 54 \mathrm{a} 2$

Silberschmidt, M. (2001). Disempowerment of men in rural and urban East Africa: Implications for male identity and sexual behavior. World Development, 29(4), 657-671. doi:10.1016/S0305-750X(00)00122-4 Uchendu, E. (2007). Masculinity and Nigerian youths. Nordic Journal of African Studies, 16(2), 279-297. Retrieved from https://www.njas.fi/njas/article/view/71/64

Isaac Dery, Institute for Social and Health Sciences of the University of South Africa, South Africa

Contact Address: Direct correspondence to Isaac Dery, Institute for Social and Health Sciences and Centre for Peace Action; p. o. Box 1087 Lenasia, 1820, South Africa, email: idery38@gmail.com 